\title{
Factors affecting the quantity and type of tree-related microhabitats in Mediterranean mountain forests of high nature value
}

\author{
Pasquale A Marziliano ${ }^{(1)}$, \\ Serena Antonucci (2), \\ Roberto Tognetti (2), \\ Marco Marchetti ${ }^{(3)}$, \\ Gherardo Chirici ${ }^{(4)}$, \\ Piermaria Corona ${ }^{(5-6)}$, \\ Fabio Lombardi ${ }^{(1)}$
}

\begin{abstract}
Tree-related microhabitats (hereafter TreMs) are structures occurring on trees, such as rot holes, cavities, large nests, mould, fruiting bodies and mycelia of decomposer fungi. TreMs have been widely recognized as important substrates and structures useful for biodiversity conservation in forest ecosystems, and they can be used as indicators for describing and monitoring forest naturalness. However, most studies on the occurrence of TreMs have been mainly done in forest ecosystems of Central Europe, while less research has been conducted in Mediterranean mountain forests. In this study, we investigated the diversity and abundance of 23 types of TreMs on living trees and on deadwood in seven Mediterranean mountains unmanaged forests located in the Apennines (Italy). The abundance of TreMs was evaluated by counting the number of TreMs per tree, while the diversity of TreMs was evaluated by means of the Shannon-Wiener index. We focused on the relationships between diversity and abundance of TreMs, and tree size (e.g., diameter, height, volume), and the time since the last harvest. Among the investigated stands, 2612 living trees, 457 standing dead trees and snags, and 1247 lying deadwood pieces were analysed. For living trees, a generalized linear mixed model was applied to test the effect of several variables on the abundance of TreMs per tree. Diameter at breast height (DBH) of tree stems influenced the abundance and diversity of TreMs. The time since the last harvest also significantly affected the probability that TreMs could be formed in a long-term perspective. The interaction of the predictors " $\mathrm{DBH}^{2}$ " and "Years since the last harvest" generated a better model than the one in which the two variables were kept separate. Indeed, these two factors together would better represent the transition of a previously managed forest to a more natural state over time. This study might provide useful information to land managers committed to forestry practices towards sustainable management and biodiversity conservation, especially referring to survey and inventory of forests of high nature value.
\end{abstract}

Keywords: Biodiversity Indicators, Forest Structure, Old-growth Forests, Tree Microhabitats, Woody Debris

\section{Introduction}

may support more species by increasing the diversity and abundance of ecological niches at small scale. These forest stands may serve as suitable reference for managnaturalness tend to have more complex horizontal and vertical structures, which ing forest in a sustainable way (Peterken 1996).

In Europe, many studies have been conducted to describe old-growth forests and their level of naturalness, focusing on their structure and composition (Emborg et al. 2000), dynamics and natural regeneration (Nagel et al. 2006), and deadwood characteristics (Stokland et al. 2012). For example, the heterogeneity in tree heights and high values of living tree volume or stand basal area have been considered features useful to characterize and increase forest naturalness (Peterken 1996). Moreover, large amounts of standing and downed dead trees, but also woody debris on the forest floor at all stages of decay, have been identified as key factors for the conservation of biodiversity in forests (Grove 2002). Most of the research focused on old-growth forests of the Mediterranean mountains has given attention to different forest structural features, such as the vertical and horizontal heterogeneity of the stand, gap dynamics, and deadwood amounts (Marchet- 
ti et al. 2010, Lombardi et al. 2012), considering also the state of conservation of habitats and veteran trees (Rosenvald \& Lõhmus 2008).

Structures such as rot holes, cavities, large nests, mould, fruiting bodies, and mycelia of decomposer fungi occurring on trees have been proposed as indicators for monitoring forest biodiversity and ecosystem integrity (Bütler et al. 2013, Paillet et al. 2018). These structures are commonly named tree-related microhabitats (hereafter TreMs). Several studies have described TreMs profile in old-growth forests (Kozák et al. 2018, Paillet et al. 2017), as well as the dynamics of TreMs in unmanaged temperate mountain mixed forests (Larrieu et al. 2014). In the original definition of Larrieu et al. (2018), TreMs are "distinct, well-delineated structures occurring on living or standing dead trees that constitute a particular and essential substrate or life site for species or communities during at least a part of their life cycle to develop, feed, shelter or breed". This definition can be also applied to TreMs occurring on lying deadwood, which hosts many saproxilic insects, fungi and lichens (Bani et al. 2018, Parisi et al. 2018).

Diversified stand structure, large deadwood amounts and the occurrence of TreMs have been linked to habitat heterogeneity and species richness, including saproxylic organisms (Bani et al. 2018, Parisi et al. 2020). Because TreMs are important substrates and structures for living organisms, they have received increasing attention in sustainable forestry, mainly for identifying habitat trees (Larrieu et al. 2017). TreMs, less explored in managed forests than in old-growth forests, can be used as indicators of biodiversity in forest monitoring schemes (Paillet et al. 2018). Many taxa, including lichens, bryophytes, fungi, insects, arthropods, small mammals and birds, rely on TreMs traits, positively affecting forest functioning (Stokland et al. 2012). Therefore, insights on the factors influencing the abundance of TreMs may al- low the implementation of scientificallysound and data-driven forest monitoring and management practices; in particular, they can be useful to identify ecologically valuable habitats for preserving forest biodiversity.

The development of TreMs can be strongly influenced by silvicultural practices and structural features (Larrieu et al. 2012, Regnery et al. 2013, Johann \& Schaich 2016). Several studies have explored the link between TreMs, management approaches and stem diameters (Winter \& Möller 2008, Michel \& Winter 2009, Vuidot et al. 2011, Paillet et al. 2019), though investigation has generally focused on living or standing dead trees (Larrieu et al. 2018). However, factors affecting numbers and types of TreMs have not been completely investigated for the different geographical regions (Paillet et al. 2017). This lack of knowledge is particularly evident in Mediterranean environments. Recent studies have focused on beech-fir forests in Central and Western Europe (Winter et al. 2005, Vuidot et al. 2011, Larrieu \& Cabanettes 2012, Larrieu et al. 2012, Larrieu et al. 2014) and only a few on Mediterranean broadleaved forests (Regnery et al. 2013, Parisi et al. 2019).

In this study, in seven unmanaged forests (without any silvicultural activities for decades or centuries) located in the Apennines (Italy), we investigated the diversity and abundance of 23 types of TreMs on the following elements: living trees, standing dead trees, snags, dead downed trees, coarse woody debris and stumps. The abundance of TreMs was obtained by counting the number of TreMs per tree, while the diversity of the several types of TreMs was evaluated through the use of diversity indices, such as the Shannon-Wiener diversity Index. We focused on the relationships between TreMs (abundance and diversity), tree size (e.g., diameter, height, volume) and time since the last harvest. We aimed at identifying which tree characteristics would support higher abundance and diversity of TreMs, providing a valuable indicator for monitoring forest biodiversity. For living trees, a generalized linear mixed model was applied to test the effect of several variables on the abundance of TreMs at the tree scale. We hypothesized a positive effect of tree stem diameters and time since the last harvest on the diversity and abundance of TreMs per tree. The magnitude of these relationships could be mainly driven both by the abandonment of silvicultural practices and by the size of individual trees (diameter, height, volume), and their interactions. Therefore, we analysed the combined effects of the time since the last harvest and the size of trees on the abundance of different TreMs.

\section{Materials and methods}

\section{Study sites}

The study was conducted in seven unmanaged forests (Tab. 1) located in the Italian Peninsula (central and southern Apennines) and characterized by different structural characteristics. The study areas are all part of natural reserves, Natura 2000 network sites or national parks, where natural development processes are the main drivers of the forest stand evolution (Tab. 1).

The elevation of the study sites ranges from 700 to $1800 \mathrm{~m}$ a.s.l. These forests are currently unmanaged, and their structural characteristics refer to high forest with diversified horizontal and vertical stand structures. They refer to pure beech forests for "Bosco Aschiero", "Fonte Novello", "Val Cervara" and "Area Pavari", whereas "Montedimezzo" is a deciduous oak-beech mixed forest; "Abeti Soprani" is a silver firbeech mixed forest, while the main species in "Collemeluccio" are silver fir and deciduous oaks. The last two study sites are both relict stands, where silver fir still occurs, surviving from the last glacial period. Their structures and tree species mixture are similar to those of native forests, throughout the Apennines, nowadays present only in small old-growth forest patches along the Italian Peninsula. This association be-

Tab. 1 - Main characteristics of the investigated forests listed for the time since the last harvest.

\begin{tabular}{|c|c|c|c|c|c|c|c|}
\hline \multirow[b]{2}{*}{ Characteristics } & \multicolumn{7}{|c|}{ Site } \\
\hline & $\begin{array}{c}\text { Abeti } \\
\text { Soprani }\end{array}$ & $\begin{array}{c}\text { Colle- } \\
\text { meluccio }\end{array}$ & $\begin{array}{l}\text { Monte- } \\
\text { dimezzo }\end{array}$ & $\begin{array}{l}\text { Area } \\
\text { Pavari }\end{array}$ & $\begin{array}{l}\text { Bosco } \\
\text { Aschiero }\end{array}$ & $\begin{array}{l}\text { Fonte } \\
\text { Novello }\end{array}$ & $\begin{array}{c}\text { Val } \\
\text { Cervara }\end{array}$ \\
\hline Location & $\begin{array}{l}\text { EU Natura } \\
2000 \text { Network } \\
\text { (Molise) }\end{array}$ & \multicolumn{2}{|c|}{$\begin{array}{c}\text { MaB Unesco Reserve } \\
\text { (Molise) }\end{array}$} & $\begin{array}{l}\text { Gargano } \\
\text { National Park } \\
\text { (Puglia) }\end{array}$ & \multicolumn{2}{|c|}{$\begin{array}{c}\text { Gran Sasso e Monti della } \\
\text { Laga National Park } \\
\text { (Abruzzo) }\end{array}$} & $\begin{array}{l}\text { Abruzzo, Lazio } \\
\text { e Molise } \\
\text { National Park }\end{array}$ \\
\hline Latitude $\mathrm{N}$ & $41^{\circ} 86^{\prime}$ & $41^{\circ} 72^{\prime}$ & $41^{\circ} 75^{\prime}$ & $41^{\circ} 82^{\prime}$ & $42^{\circ} 50^{\prime}$ & $42^{\circ} 50^{\prime}$ & $41^{\circ} 49^{\prime}$ \\
\hline Longitude $\mathrm{E}$ & $14^{\circ} 30^{\prime}$ & $14^{\circ} 35^{\prime}$ & $14^{\circ} 21^{\prime}$ & $15^{\circ} 99^{\prime}$ & $13^{\circ} 58^{\prime}$ & $13^{\circ} 50^{\prime}$ & $13^{\circ} 43^{\prime}$ \\
\hline Forest area (ha) & 232 & 374 & 291 & 5.4 & 5.2 & 13.4 & 300 \\
\hline Altitudinal range (m a.s.l.) & $1250-1450$ & $900-1000$ & $950-1050$ & $720-800$ & $1580-1640$ & $1320-1360$ & $1730-1830$ \\
\hline Mean annual temperature $\left({ }^{\circ} \mathrm{C}\right)$ & 8.4 & 9.2 & 8.6 & 11.6 & 10 & 10 & 7.2 \\
\hline Mean annual precipitation (mm) & 1124 & 960 & 1022 & 1041 & 1246 & 1071 & 1211 \\
\hline Main tree species & silver fir & fir-beech & oak-beech & beech & beech & beech & beech \\
\hline Mean age of living trees (yrs) & 131 & 121 & 139 & 164 & 170 & 152 & 262 \\
\hline Time since the last harvest (yrs) & 31 & 51 & 56 & 58 & 310 & 312 & $>500$ \\
\hline
\end{tabular}


comes more stable in less fertile sites, where beech is less competitive.

The beech forests of "Bosco Aschiero" and "Fonte Novello" are within the "Gran Sasso e Monti della Laga" National Park. The "Fonte Novello" forest has not been managed in the last centuries, due to legal debates concerning the position of the administrative boundaries between municipalities. Whereas, "Bosco Aschiero" has escaped from logging practices, developing old-growth structural characteristics, due to the rocky and steep terrain. The beech high forest of "Val Cervara" is included in the "Abruzzo, Lazio e Molise" National Park. This forest has been included within the UNESCO Heritage sites, as one of the "Ancient and primeval beech forests of the Carpathians and other regions of Europe". It has been unmanaged for centuries, due to difficult access, and because of its protective role against avalanches.

Furthermore, the "Abeti Soprani" forest is no longer managed and has not been logged for more than three decades, due to the low interest for conifer timber in the local context. "Collemeluccio" and "Montedimezzo" forests are part of the "Collemeluccio-Montedimezzo Alto Molise" MaB Unesco Reserve and have been unmanaged for the last 50-60 years. Finally, the beech high forest of "Area Pavari", located in the "Gargano" National Park, is part of an oldgrowth forest research network established in 1952; it has been unmanaged since 1954. For further details regarding the study sites, see Lombardi et al. (2012).

\section{Survey of living trees and deadwood components}

At each site, a 1-ha wide square plot was established and clearly delimited. One hectare was chosen because old-growth forest traits are usually characterized by high horizontal heterogeneity and a single large plot may better capture the structural diversity of a forest than several small plots (Lombardi et al. 2015).

The main forest stand attributes were recorded, measuring for each species the diameter at breast height $(\mathrm{DBH} \geq 10 \mathrm{~cm})$ and the total height for all the living trees and standing dead trees (SDT); the total length was measured for dead downed trees (DDT). In addition, the minimum and maximum diameter and length were recorded for snags (minimum diameter $\geq 5$ $\mathrm{cm}$ ), coarse woody debris (CWD - minimum diameter $\geq 5 \mathrm{~cm}$ and minimum length $\geq 1 \mathrm{~m}$ ), and stumps (minimum diameter $\geq 5$ $\mathrm{cm})$. SDT and DDT were characterized by the presence of crown (dead branches and twigs), while snags were stems without crown (short broken bole, little bark remaining, soft wood); CWD refers to the remains of large branches or stem portions or large woody debris lying on the forest floor. A threshold height of $1.3 \mathrm{~m}$ was used to distinguish stumps (less than $1.3 \mathrm{~m}$ ) from snags (higher than $1.3 \mathrm{~m}$ ). Living trees, SDT, snags and stumps were mea-

Tab. 2 - Description of the 23 types of TreMs censused in the study sites (modified from Winter \& Möller 2008).

\begin{tabular}{|c|c|}
\hline $\begin{array}{l}\text { ID } \\
\text { TreMs }\end{array}$ & TreMs description \\
\hline M1 & Occurrence of fruiting bodies of Fomes fomentarius \\
\hline M2 & Occurrence of fruiting bodies of Fomitopsis pinicola \\
\hline M3 & Occurrence of other fungal infection \\
\hline M4 & Crown broken $<50 \%$ \\
\hline M5 & Several main branches are broken: $>50 \%$ of the crown broken \\
\hline M6 & Broken fork: complete fracture of one of the two forking branches \\
\hline M7 & $\begin{array}{l}\text { Broken stem: the crown is totally absent and very small living twigs have } \\
\text { remained }\end{array}$ \\
\hline M8 & Substitute or secondary crown \\
\hline M9 & Lightning scar at least $3 \mathrm{~m}$ long and reaching the sapwood \\
\hline M10 & Crack: cleft into the sapwood $>50 \mathrm{~cm}$ long along the stem and at least $2 \mathrm{~cm}$ deep \\
\hline M11 & Splintered stem: the split-up results in numerous scales of wood $>50 \mathrm{~cm}$ long \\
\hline M12 & Cavities with $>5 \mathrm{~cm}$ aperture \\
\hline M13 & Cavity string: at least three woodpecker cavities \\
\hline M14 & Deep stem cavities: a tubular cavity with little or without mould \\
\hline M15 & Cavities with mould of at least $8000 \mathrm{~cm}^{3}$ \\
\hline M16 & Mould pockets: space between loose bark and the sapwood \\
\hline M17 & Bark pockets: same structure as $M 16$, but without mould \\
\hline M18 & Canker: proliferation of cell growth at least $10 \mathrm{~cm}$ in diameter \\
\hline M19 & $\begin{array}{l}\text { Bark loss: patches with bark loss of at least } 5 \mathrm{~cm} \text { caused by natural falling of } \\
\text { trees }\end{array}$ \\
\hline M20 & Uprooted stump, with a minimum height of $1.20 \mathrm{~m}$ of the vertical root plate \\
\hline M21 & System of gallery of Scolytidae insects \\
\hline M22 & Saproxylic insect holes \\
\hline M23 & Water filled rot hole on stump \\
\hline
\end{tabular}

sured when more than half the base of their trunk occurred within the plot. CWD and DDT were measured when more than half the base of its thicker end occurred within the plot (more details can be found in Lombardi et al. 2012).

The volume of living trees, SDT and DDT was calculated by double-entry volume equations (Tabacchi et al. 2011), while the volume of snags, CWD and stumps was computed as follows (eqn. 1):

$$
V=\pi \cdot \frac{h}{3} \cdot\left[\left(\frac{D}{2}\right) \cdot 2+\left(\frac{d}{2}\right) \cdot 2+\left(\frac{D}{2}\right) \cdot\left(\frac{d}{2}\right)\right]
$$

where $V$ is the volume $\left(\mathrm{m}^{3}\right), h$ is the height or length $(m), D$ is the maximum diameter $(\mathrm{m})$ and $d$ is the minimum diameter $(\mathrm{m})$.

Decay stage of each deadwood piece was classified visually, using the five-grade scale proposed by Hunter (1990), in which the morphological characteristics of deadwood are assessed. Further details on the applied sampling protocol are available in Lombardi et al. (2012).

\section{Assessment of microhabitats}

In this survey, we referred to a set of 23 types of TreMs, according to Winter \& Möller (2008), with minor changes (Tab. 2). Although new survey schemes have been made available (Larrieu et al. 2018), which will enable standardized TreMs recording in future forest inventories, local monitoring schemes still refer to the classification of Winter \& Möller (2008).

In each study site, we recorded the TreM type and the abundance of TreMs occurring on each living tree and deadwood component. We carefully examined the entire living and standing dead tree, but also all the horizontal deadwood elements occurring on the forest floor. In total, 2612 living trees, 457 SDT and snags, and 1247 CWD were individually and exhaustively inspected. Some TreMs were recorded only on living trees, such as those on branches and broken crowns (M4-M8), and others on stems (M9-M11 and M14-M19). M5 was visually estimated with binoculars, while M16 and M17 were measured in their length and deepness in the trunk, in order to distinguish them from each other. Finally, M21 and M22 were counted if their extension was higher than $0.5 \mathrm{~m}^{2}$. All the censused TreMs were linked to the forest components on which they were observed (living trees, SDT, snags, DDT, CWD, stumps).

\section{Data analysis}

In each site, we recorded the diversity of each type of TreMs (M1, M2, M3 etc) and the abundance of TreMs on each living trees and on five deadwood components. 
Tab. 3 - Main structural and dendrometric features of the seven study sites. (BA): basal area; $\left(\mathrm{V}_{\text {live }}\right)$ : living tree volume; $\left(\mathrm{V}_{\text {dead }}\right)$ : Deadwood volume.

\begin{tabular}{lcccccc}
\hline Site & $\begin{array}{c}\text { Trees } \\
\left(\mathbf{n ~ h a} \mathbf{~}^{-1}\right)\end{array}$ & $\begin{array}{c}\text { Mean } \\
\mathrm{DBH} \\
(\mathbf{c m})\end{array}$ & $\begin{array}{c}\mathrm{BA} \\
\left(\mathrm{m}^{2} \mathbf{h a}^{-1}\right)\end{array}$ & $\begin{array}{c}\mathbf{V}_{\text {live }} \\
\left(\mathbf{m}^{3} \mathbf{h a}^{-1}\right)\end{array}$ & $\begin{array}{c}\mathrm{V}_{\text {dead }} \\
\left(\mathbf{m}^{3} \mathbf{h a}^{-1}\right)\end{array}$ & $\begin{array}{c}\mathbf{V}_{\text {dead }} / \\
\left(\mathbf{V}_{\text {livive }}+\mathbf{V}_{\text {dead }}\right) \\
(\%)\end{array}$ \\
\hline Abeti Soprani & 591 & 34.8 & 56.3 & 569.8 & 95.6 & 14.4 \\
\hline Collemeluccio & 570 & 32.1 & 46.1 & 557.8 & 17.4 & 3.0 \\
\hline Montedimezzo & 344 & 40.4 & 44.0 & 702.5 & 26.5 & 3.6 \\
\hline Area Pavari & 191 & 49.8 & 37.2 & 666.3 & 89.5 & 11.8 \\
\hline Bosco Aschiero & 277 & 48.4 & 51.1 & 584.1 & 21.3 & 3.5 \\
\hline Fonte Novello & 406 & 44.3 & 62.7 & 1070.3 & 88.9 & 7.7 \\
\hline Val Cervara & 233 & 37.0 & 25.1 & 363.6 & 143.0 & 28.2 \\
\hline Mean & 373 & 41.0 & 46.1 & 644.9 & 68.9 & 10.3 \\
\hline SD & 158 & 6.8 & 12.4 & 216.3 & 47.9 & 9.0 \\
\hline
\end{tabular}

In our analyses, we considered two variables: (1) the variable "abundance of TreMs per tree", considered as the sum of the TreMs counted on each living tree and/or deadwood component; (2) the variable "diversity of TreMs", based on the number of the different types of TreMs (Tab. 2) occurring on each living tree and/or deadwood component. The TreMs diversity was evaluated through the Shannon diversity index (Shannon 1948).

In order to verify the differences among the Shannon diversity index values, between components and among sites, the confidence intervals were calculated through a bootstrap procedure (Dixon 1993). Furthermore, to assess the significance, the PERMANOVA statistical test (Permutational Analysis of Variance) was applied: it considers the values of similarities without any assumption about the data distribution (McArdle \& Anderson 2001). Then, the PERMANOVA test verifies the simultaneous responses of one or more variables for one or more factors in an ANOVA experimental model, calculating the $\mathrm{p}$-values through permutations (Marti 2001).

Differences between the considered components (living trees, SDT, DDT, snag, CWD and stump) in the number of TreMs per element were verified based on the whole dataset, using the Kruskal-Wallis test ("coin" package for the $\mathrm{R}$ programming language) and the pair-wise Conover test ("PMCMR" package for the R programming language). In all comparisons, the significance was associated to the critical value $p \leq 0.05$

For living trees, we tested the effect of several independent variables, or their combination, on TreMs number per tree, using different models. The variables were the following: (1) time since the last harvest (YEAR); (2) stem diameter (DBH); (3) tree height (HT); (4) height of crown insertion point (HC); (5) stem volume (VOL), interaction between $\mathrm{DBH}^{2}$ and YEAR, expressed as $\mathrm{DBH}^{2}$ - YEAR. Models were run over the whole set of available independent variables (in total 2612 trees, whose 209 with at least one TreMs and 2403 with zero TreM), based on a linear mixed model, including both fixed and random effects. The independent variables were used as fixed-effect predictors. The site ID was added as random effect. The analysis considered as possible the incorporation of the random effects in the model, allowing the non-independence of observations ( $\mathrm{Zu}$ -
Fig. 1 - Number of trees per hectare in relation to the diameter classes (10 $\mathrm{cm})$ in the seven study sites.

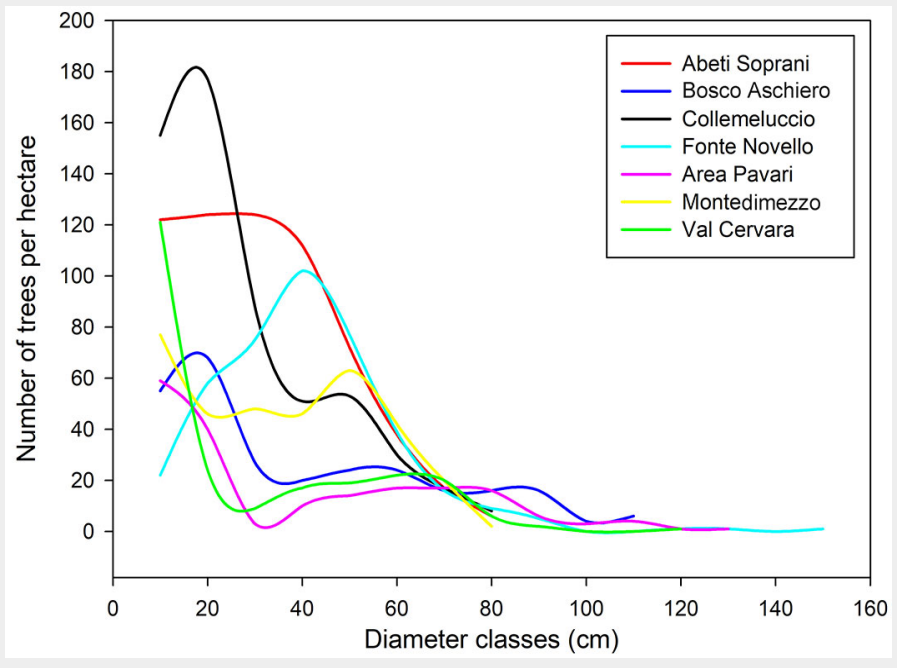

ur et al. 2013). Since the "number of TreMs" referred to count data with an excess of zeros, we used a zero-inflated Poisson error distribution for applying the above cited models. This model was able to handle both the presence/absence of TreMs and their abundance (i.e., the number of TreMs per tree - Lambert 1992).

The following models were compared for testing the effect of the above-mentioned variables on the number of TreMs per tree: - Model [1-5]: One-variable models (YEAR, $\mathrm{DBH}, \mathrm{HT}, \mathrm{HC}, \mathrm{VOL})$;

- Model [6]: Complete additive model (YEAR+DBH+HT+HC+VOL);

- Model [7]: Combined model (DBH'.YEAR). We fitted these models based on the Akaike Information Criterion (AIC); for model [6], we used a stepwise procedure (in each step, a variable was considered for addition to or subtraction from the set of explanatory variables based on F-tests). This process allowed to simplify the mod els, then obtaining more efficient statistics. Results of the model were considered significant at a probability level of $5 \%$. Among the compared models (based on the variables specified above), the model with the lowest Akaike Information Criterion (AIC) value was selected. In addition, for the selected model, VIF (variance inflation factor) was analysed to check for multicollinearity. For the GLMMs, the "glmmTMB" in the TMB package for the $R$ programming language ( $R$ Core Team 2019) was used.

\section{Results}

Forest features and deadwood amounts The main forest attributes of the investigated stands are shown in Tab. 3.

Structural characteristics differed among the studied stands, with a number of trees per hectare varying from 191 in Area Pavari to 591 in Abeti Soprani. Living tree volume ranged between 364 and $1070 \mathrm{~m}^{3} \mathrm{ha}^{-1}$, with the lowest values recorded in the beech forest of Val Cervara and the highest in Fonte Novello. All the studied stands showed a multi-sized diameter distribution of living trees (Fig. 1), with the occurrence of a high number of tree diameter classes.

Although with varying trends, each study site displayed a decreasing number of living trees as the diameter classes increased. The highest number of trees with the lowest stem DBH was found in Collemeluccio, whereas Fonte Novello and Area Pavari had trees with the largest stem DBH. Trees with stem DBH larger than $80 \mathrm{~cm}$ were mainly observed in Bosco Aschiero and Val Cervara, while they were totally absent in Montedimezzo and Abeti Soprani. Deadwood volume showed a large variability among the study sites (Tab. 3), ranging between 17.4 $\mathrm{m}^{3} \mathrm{ha}^{-1}$ in Collemeluccio and $143.0 \mathrm{~m}^{3} \mathrm{ha}^{-1}$ in Val Cervara. Considering all the study sites, an average deadwood volume of $68.9 \mathrm{~m}^{3}$ $\mathrm{ha}^{-1}$ was found, with a standard deviation (SD) of $47.9 \mathrm{~m}^{3} \mathrm{ha}^{-1}$. The proportion of deadwood volume was also reported in re- 
lation to the overall stand volume (living trees plus deadwood components). Val Cervara was characterized by the largest proportion of deadwood (28.2\% of the total volume), while the other sites showed deadwood proportions lower than 10\%, with the exception of Abeti Soprani and Area Pavari, where the proportion was $14.4 \%$ and $11.8 \%$, respectively.

\section{Abundance of microhabitats}

The abundance of TreMs (as number of TreMs) significantly varied among the study sites and between the different components. Tab. 4 reports the total number of TreMs and the number of TreMs per living tree and per each deadwood component.

The survey on the 2612 living trees revealed a total number of 362 TreMs. Only $10.4 \%$ of living tree had at least one TreM (Tab. 4). Considering all the study sites, on average, 52 TreMs were found for living trees with a standard deviation of 47 and high heterogeneity across the study sites. The highest number of TreMs was recorded in the sites unmanaged for more than one century, namely Fonte Novello (64 TreMs), Bosco Aschiero (91 TreMs), and Val Cervara (133 TreMs).

On average, 0.19 TreMs per living tree, with a SD of 0.2 were observed. Particularly, they increased with long time since the last harvest, as in Val Cervara ( 0.57 TreMs per tree) and Bosco Aschiero ( 0.33 TreMs per tree). The lowest number of TreMs per tree was recorded in Abeti Soprani (0.01 TreM per tree) and Collemeluccio ( 0.02 TreMs per tree), both characterized by short time since the last harvest (30-50 years).

The abundance of TreMs (N-TreMs) was higher on deadwood components than on living trees. The survey on the 1704 deadwood components revealed a total of 1178 TreMs, occurring on 505 deadwood components. About $30 \%$ of deadwood elements had at least one TreM (Tab. 4). A higher number of TreMs was observed in the sites unharvested for very long time, namely Fonte Novello (316 TreMs) and Val Cervara (596 TreMs).

On average, 0.71 TreMs, with a SD of 0.96 , were recorded on deadwood components, revealing a higher value than that obtained for living trees (0.19 TreMs per tree). The highest number of TreMs per deadwood component was recorded in Val Cervara (2.64), characterized by a long time since the last harvest, in Fonte Novello (1.14) and in Area Pavari (0.54), where the presence of living trees and deadwood components with high diameter values was more frequent.

In Fig. 2 the mean values of TreMs and their variability are reported for living trees and deadwood components; the observed variability was always very high. The largest number of TreMs per element was found on snags (1.4), CWD (0.8) and DDT (0.8), while less TreMs per element were
Tab. 4 - Abundance of TreMs on living trees and deadwood components. (Year): time since the last harvest; (No): number of trees (for living trees) and number of woody debris (for deadwood components) with presence of at least one TreM; (No-Tr \%): percentage of living trees or deadwood components with at least one TreMs; ( $\mathrm{N}$ TreM): total number of TreMs; (M-TreM): mean number of TreMs per tree \pm standard deviation; (SD): standard deviation.

\begin{tabular}{|c|c|c|c|c|c|c|}
\hline Components & Site & Year & No & No-Tr \% & $\mathrm{N}$-TreM & M-TreM \\
\hline \multirow{9}{*}{ 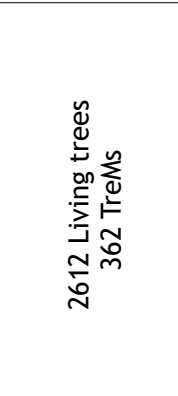 } & Abeti Soprani & 31 & 6 & 1.0 & 6 & $0.01 \pm 0.10$ \\
\hline & Collemeluccio & 51 & 9 & 1.6 & 11 & $0.02 \pm 0.16$ \\
\hline & Montedimezzo & 56 & 17 & 4.9 & 23 & $0.07 \pm 0.31$ \\
\hline & Area Pavari & 58 & 17 & 8.9 & 34 & $0.18 \pm 0.71$ \\
\hline & Bosco Aschiero & 310 & 50 & 18.1 & 91 & $0.33 \pm 0.85$ \\
\hline & Fonte Novello & 312 & 50 & 12.3 & 64 & $0.16 \pm 0.48$ \\
\hline & Val Cervara & $>500$ & 60 & 25.8 & 133 & $0.57 \pm 1.18$ \\
\hline & Mean & - & 30 & 10.4 & 52 & 0.19 \\
\hline & $S D$ & - & 23 & 9.1 & 47 & 0.20 \\
\hline \multirow{9}{*}{ 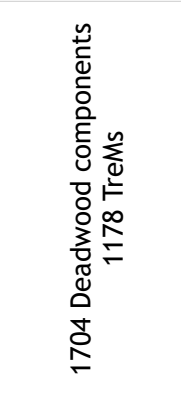 } & Abeti Soprani & 31 & 35 & 8.8 & 75 & $0.20 \pm 0.65$ \\
\hline & Collemeluccio & 51 & 38 & 14.8 & 64 & $0.25 \pm 0.67$ \\
\hline & Montedimezzo & 56 & 5 & 2.6 & 12 & $0.05 \pm 0.40$ \\
\hline & Area Pavari & 58 & 37 & 20.9 & 91 & $0.54 \pm 1.11$ \\
\hline & Bosco Aschiero & 310 & 12 & 6.8 & 24 & $0.13 \pm 0.52$ \\
\hline & Fonte Novello & 312 & 153 & 54.1 & 316 & $1.14 \pm 1.10$ \\
\hline & Val Cervara & $>500$ & 225 & 100.0 & 596 & $2.64 \pm 1.67$ \\
\hline & Mean & - & 72 & 29.7 & 168 & 0.71 \\
\hline & $S D$ & - & 83 & 35.4 & 214 & 0.96 \\
\hline
\end{tabular}

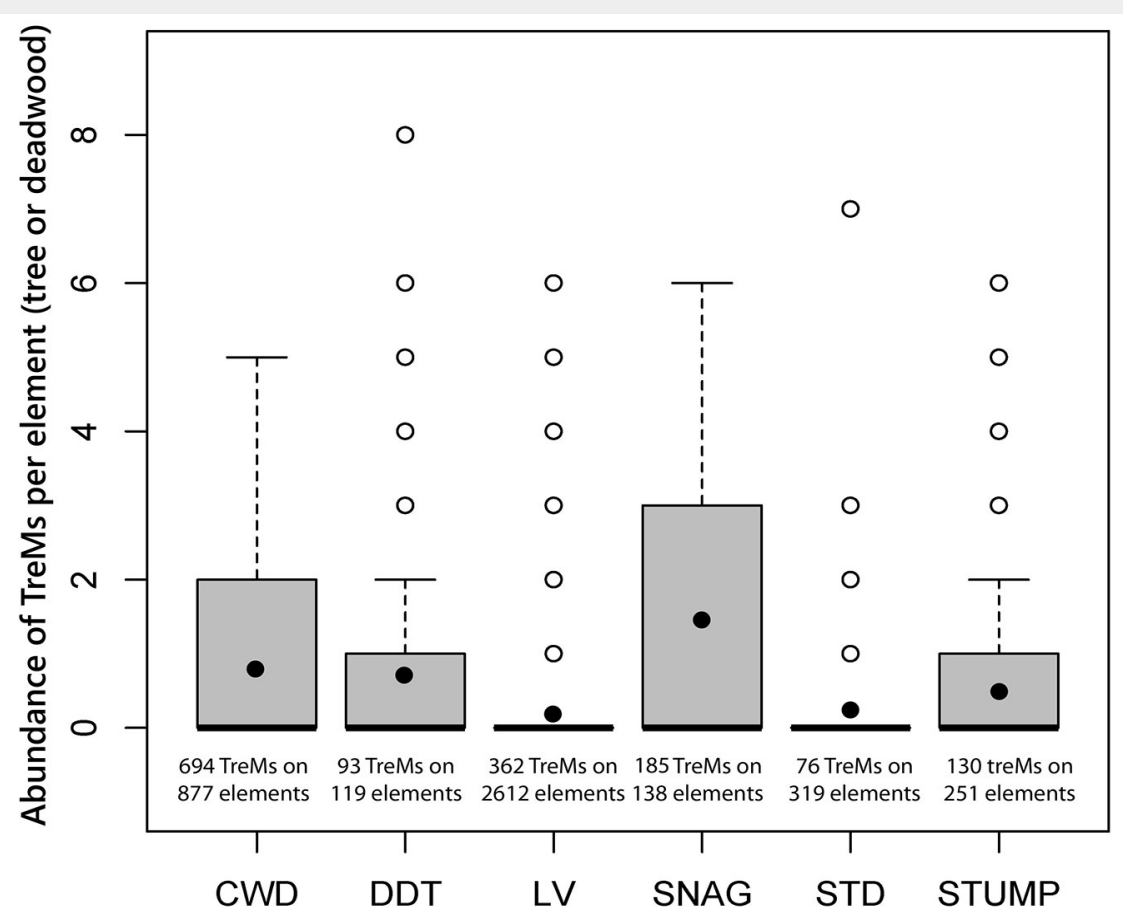

Fig. 2 - Number of TreMs recorded on each element (living trees and deadwood components) and represented as box-plot distributions: CWD (coarse woody debris), DDT (dead downed trees), LV (living trees), SDT (standing dead trees), snags and stumps. In the box plot, the upper limit corresponds to the value of the first quartile (Q1) of the distribution and the lower limit to the third quartile (Q3); the heavy horizontal line is the median. Errors bars connect the two extreme values, obtained as a linear combination of Q1 and Q3 values. Cases with values more than three-box lengths, from the upper or lower edge of the box, are shown as open circles. The closed circles inside the box is the mean number of TreMs per element. The Kruskal-Wallis test and the pairwise Conover non-parametric test were applied. 


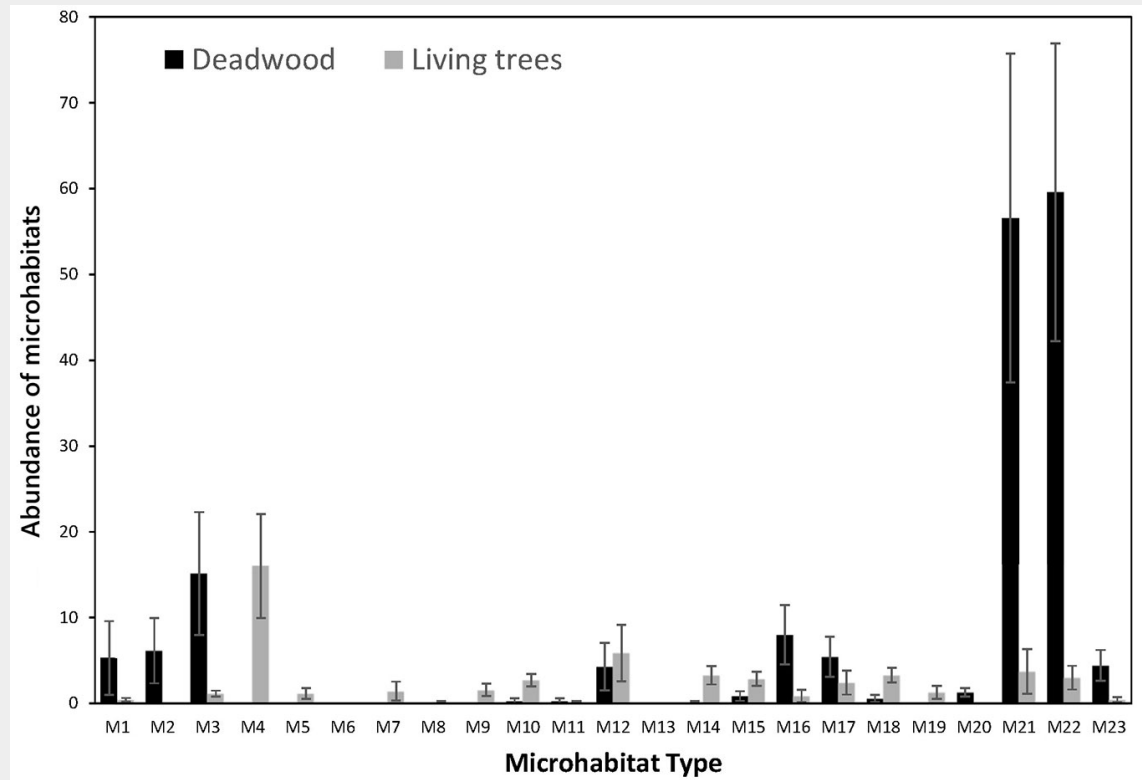

Fig. 3 - Number of each type of TreMs (average values and related variability), occurring in all sites divided by types, for living trees and for deadwood components. The error bars represent the standard deviation of the mean.

recorded on living trees (0.2) and STD (0.3). Moreover, the Kruskal-Wallis test revealed highly significant differences (Kruskal-Wallis $\chi^{2}=514.88, \mathrm{df}=5, \mathrm{p}<0.0001$ ) between medians. The pair-wise Conover test showed significant difference between snags, CWD and DDT and all the other components, while no significant differences were observed between living trees and STD. Furthermore, the number of TreMs for each element was always higher in sites where human-related disturbances had not occurred for more than 300 years. Finally, among the deadwood components, in absolute terms, the highest number of TreMs occurred on CWD (694) and on snags (185), while the lowest number of TreMs was observed on SDT (76).
Fig. 3 shows, for each type of TreMs, the total number of TreMs recorded on living trees and deadwood components. A high number of M21 (on average 58) and M22 (on average 60) was observed on deadwood components, strictly linked to the activity of saproxylic insects. Fungal structures (M1, M2, and $\left.M_{3}\right)$ were almost exclusively present on deadwood components, especially on the CWD. On average, these TreMs ranged between 6 for M1 and 16 for M3. On living tree, the above mentioned TreMs (fungi) also occurred, but outnumbered. Cavities were frequently represented by $\mathrm{M} 12$, characterizing mostly living trees (on average 6 TreMs) and, to a lesser extent, deadwood components, mainly snags. Also, other cavities with or without mould (M14 and M15), occurred more frequently on living trees than on deadwood components, while the bark loss was recorded only on living trees (M19). Finally, two types of TreMs were totally absent, M6 (broken forks) and M13 (cavity strings).

\section{Diversity of microhabitats}

The variability and the mean values of the Shannon diversity index (SI) related to TreMs diversity, for each investigated component and for all the study sites, are reported in Fig. 4. PERMANOVA analysis showed that SI was significantly higher in living trees than in all the deadwood components. Particularly, a higher diversity of TreMs was observed in Area Pavari, Fonte Novello and Val Cervara more than the other study sites. These three sites differed from the other for the time since the last harvest (about 60 years for Area Pavari and more than 300 years for Fonte Novello and Val Cervara), but they had similar structural stand characteristics, in particular the occurrence of trees with stem DBH higher than $80 \mathrm{~cm}$. Conversely, Collemeluccio and Abeti Soprani showed the lowest SI; these study areas had the highest number of trees with stem DBH ranging between 10 and $30 \mathrm{~cm}$, but also unmanaged for $30-50$ years. Moreover, a positive correlation between $\mathrm{SI}$ and the years since the last harvest was observed for living trees, while no correlations were observed for all the other components.

DDT were found only in three sites (Area Pavari, Fonte Novello and Val Cervara), showing high diversity of TreMs (mean SI = 1.63). Area Pavari was characterized by the presence of trees with high DBH values. A lower SI (on average, 1.43) was found for snags, with the highest value found in Val Cervara (2.04). However, the PERMANOVA test showed no significant differences for the diversity of TreMs between snags and DDT. Also, CWD, SDT and stumps had the

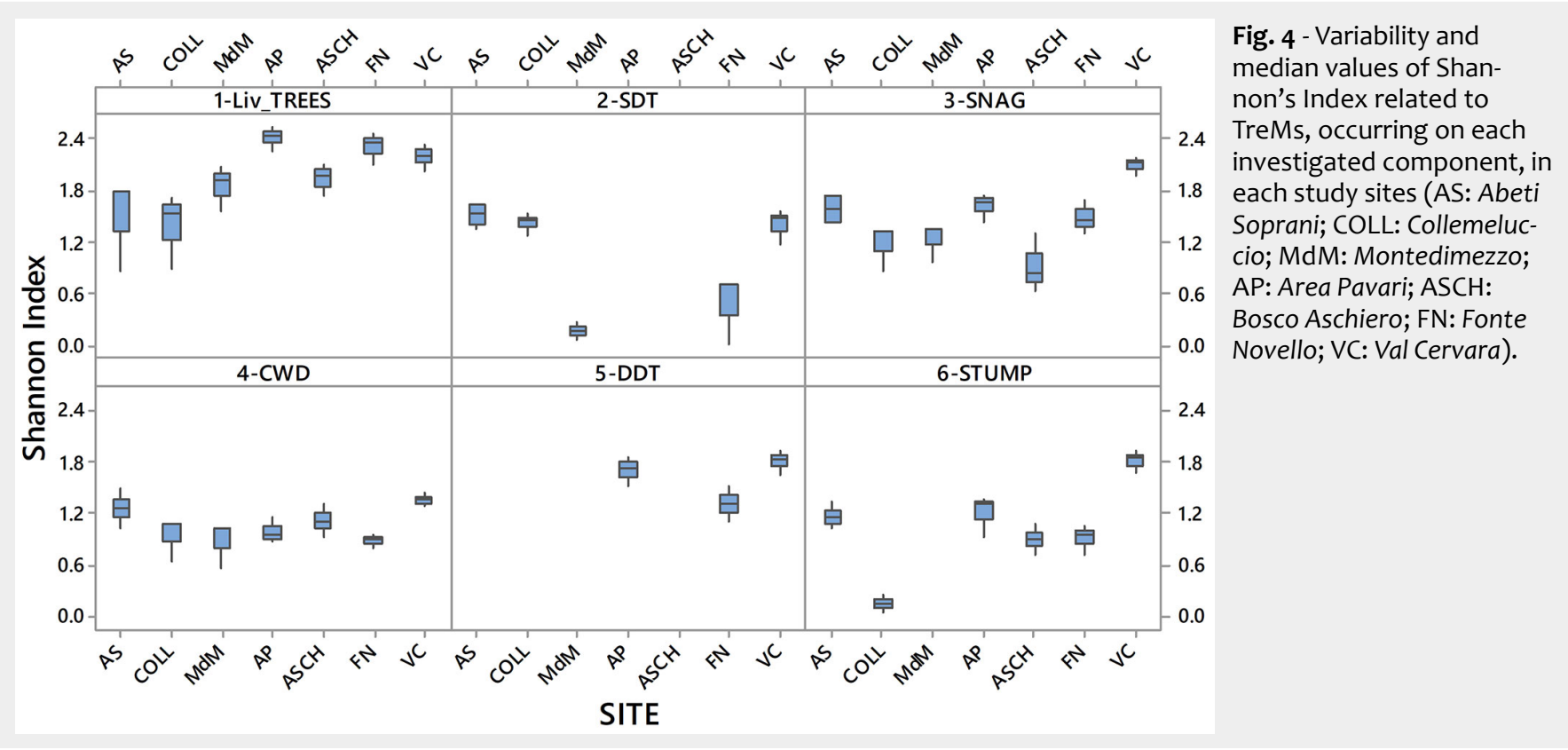


lowest diversity of TreMs, with SI ranging between 1.02 and 1.06, without significant differences between these components. The SI obtained for CWD was similar in all sites, while for SDT and stumps the lowest values were recorded in Montedimezzo and collemeluccio.

\section{Correlation between variables and modelling of number of microhabitats per tree}

Significant correlations between the number of TreMs and the diameter of deadwood elements $(r=0.37 ; p<0.001)$, the deadwood length $(r=0.31 ; p<0.001)$, and the time since the last harvest $(r=0.55$; $\mathrm{p}<0.001)$ were observed. Moreover, a significant correlation between the deadwood volume and the number of TreMs $(r=0.34 ; p<0.001)$ was also observed, while the deadwood decay stage $(r=0.14 ; p=0.125$ did not influence the number of TreMs.

For living trees, the number of TreMs were significantly correlated with the diameter of tree stems $(r=0.42 ; p<0.001)$ and the time since the last harvest $(r=0.37$; $\mathrm{p}<0.001)$, but also with the tree volume $(r=0.27 ; p<0.001)$. Conversely, no significant correlations were found between tree height $(r=0.022 ; p=0.264)$ or the height of crown insertion point $(r=0.06 ; p=0.758)$ and number of TreMs.

Tab. 5 shows the results of the linear mixed model procedure applied to the models [1-7] to test the effect of the considered variables on the number of TreMs per living tree. In the one-variable models each model was significant, even if the model with the lowest AIC value was the model [1], with diameter as the predictive variable $($ AIC $=1677)$. In the complete additive model [6], the stepwise procedure eliminated all variables (in each step, a variable was considered for addition to or subtraction from the set of explanatory variables based on F-tests), except for the DBH and YEAR, the only variables that had a significant effect on the number of TreMs per living tree, but with a higher AIC value (1779) than in model [1].

By comparing and transforming several combinations of these two variables, we found that the model with the lowest AIC value (1465) was the combined model between squared DBH and YEAR, expressed as a single predictor $\left(D B H^{2} \cdot Y E A R\right)$. Therefore, the model [7] was the model that estimated better the number of microhabitats per tree. Finally, for this model, the variance inflation factor (VIF) was lower than 2; therefore, the absence of multicollinearity was supported (Zuur et al. 2010). Based on this model, the number of TreMs per living tree increased when tree diameter and the time since the last harvest were higher (Fig. 5).

\section{Discussion}

This study aimed at identifying tree attributes associated with higher number and diversity of TreMs, supporting the sur-
Tab. 5 - Values of the estimates derived from generalized fixed and random effects models to test the effect of independent variables on abundance of TreMs per living tree. The independent variables were the following: tree DBH; (YEAR): years since the last harvest; (HT): tree height; (HC): height of crown insertion point; (VOL): tree volume. The selected model is [7]. Models were run over the whole dataset (in total 2612 trees). $(* * *): p<0.0001$

\begin{tabular}{|c|c|c|c|c|c|c|}
\hline Model & Variable & Estimate & Std. Error & z-value & $\operatorname{Pr}(>|z|)$ & AIC \\
\hline \multirow[t]{2}{*}{ [1] One-variable } & Intercept & -0.1129 & 0.0785 & -8.708 & $<2.0 \mathrm{e}-16^{* * *}$ & \multirow[t]{2}{*}{1677} \\
\hline & DBH & 0.0088 & 0.0005 & 19.096 & $<2.0 \mathrm{e}-16^{* * *}$ & \\
\hline \multirow[t]{2}{*}{ [2] One-variable } & Intercept & -0.0041 & 0.0541 & -7.594 & $3.1 e-14^{* * *}$ & \multirow[t]{2}{*}{2021} \\
\hline & YEAR & 0.0010 & 0.0002 & 3.568 & $0.00036^{* * *}$ & \\
\hline \multirow[t]{2}{*}{ [3] One-variable } & Intercept & -0.0640 & 0.0911 & -7.267 & $3.69 \mathrm{e}-13^{* * *}$ & \multirow[t]{2}{*}{1905} \\
\hline & $\mathrm{HT}$ & 0.0128 & 0.0015 & 11.109 & $<2.0 \mathrm{e}-16^{* * *}$ & \\
\hline \multirow[t]{2}{*}{ [4] One-variable } & Intercept & 0.1219 & 0.0853 & -5.177 & $2.26 \mathrm{e}-07^{* * *}$ & \multirow[t]{2}{*}{2010} \\
\hline & $\mathrm{HC}$ & 0.0069 & 0.0025 & 4.255 & $2.09 \mathrm{e}-05^{* * *}$ & \\
\hline \multirow[t]{2}{*}{ [5] One-variable } & Intercept & 0.0389 & 0.0769 & -5.767 & $8.09 \mathrm{e}-09^{* * *}$ & \multirow[t]{2}{*}{1685} \\
\hline & VOL & 0.0767 & 0.0038 & 19.634 & $<2.0 \mathrm{e}-16^{* * *}$ & \\
\hline \multirow{6}{*}{$\begin{array}{l}\text { [6] Additive } \\
\text { complete }\end{array}$} & Intercept & 0.0292 & 0.0581 & -12.060 & $<2.0 \mathrm{e}-16^{* * *}$ & \multirow[t]{6}{*}{1799} \\
\hline & DBH & 0.0049 & 0.0011 & 10.300 & $<2.0 \mathrm{e}-16^{* * *}$ & \\
\hline & YEAR & 0.0008 & 0.0002 & 4.590 & $4.43 \mathrm{e}-06^{* * *}$ & \\
\hline & $\mathrm{HT}$ & -0.0116 & 0.0026 & -1.672 & 0.0945 & \\
\hline & $\mathrm{HC}$ & -0.0079 & 0.0033 & -0.544 & 0.5866 & \\
\hline & VOL & 0.0702 & 0.0071 & -0.059 & 0.9531 & \\
\hline \multirow{2}{*}{$\begin{array}{l}\text { [7] Combined } \\
\text { model }\end{array}$} & Intercept & 0.0032 & 0.0453 & -15.491 & $<2.0 \mathrm{e}-16^{* * *}$ & \multirow[t]{2}{*}{1465} \\
\hline & $\mathrm{DBH}^{2} \cdot$ YEAR & $5.38 \mathrm{e}-07$ & $2.00 \mathrm{e}-08$ & 19.276 & $<2.0 \mathrm{e}-16^{* * *}$ & \\
\hline
\end{tabular}

vey of forest biodiversity in Mediterranean spective. This indicates that forests left unmountain environments. The size of trees, managed for a long time (centuries) will in particular stem DBH, was strongly asso- develop structural elements for higher diciated with both the abundance and the di- versity and abundance of TreMs per each versity of TreMs. In addition, the time since component, in comparison with stands in the last harvest also had an important role, which the last harvest dates back a few significantly affecting the probability that decades (Regnery et al. 2013). The analyses TreMs could be formed in a long-term per- recognized the stem DBH as the most rele-

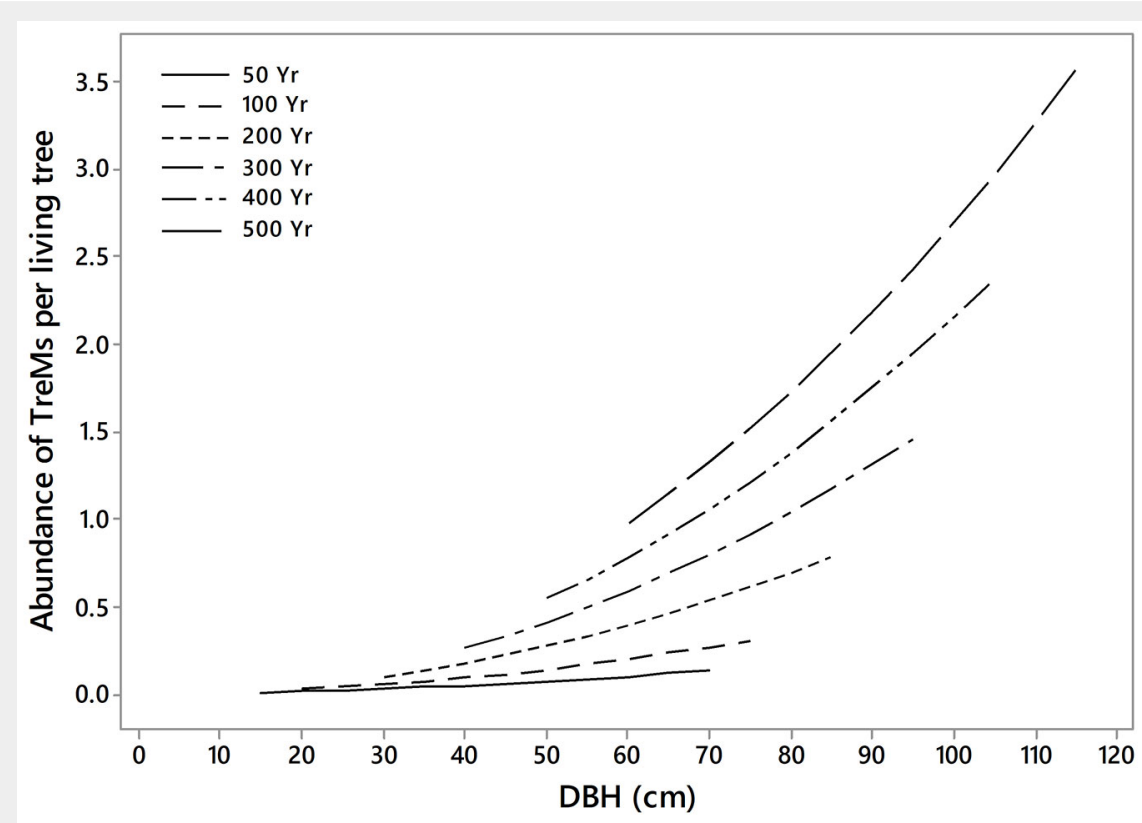

Fig. 5 - Number of TreMs per tree in relation to the diameter at breast height of trees (DBH) and to the years since the last harvest (YEAR) based on raw data. The two variables are expressed as single predictor $\left(\mathrm{DBH}^{2} \cdot\right.$ YEAR). Sample size $=2612$ trees. 
vant dendrometric parameter useful to monitor and assess the number of TreMs per living tree, followed by the time since the last harvest. The combination of DBH and time since the last harvest provided a better model than including the two variables separately, in part due to the relationship between these two predictors, but also because these two factors together may better represent the transition of a previously managed forest to a more natural state over time.

A positive relationship between the stem $\mathrm{DBH}$ and the abundance of TreMs was also observed in other environmental conditions (Larrieu \& Cabanettes 2012, Larrieu et al. 2012, Regnery et al. 2013, Vuidot et al. 2011). However, this relationship cannot be generalized. Indeed, in the forest stands investigated in this study, when the last harvest dated back a few decades, the abundance of TreMs did not vary significantly as the stem DBH increased. These results are coherent with the observations of Winter \& Möller (2008), who found no significant relationships between the stem DBH and the abundance of TreMs in managed forests and in stands in which the last harvest dated back a few decades. However, Paillet et al. (2019) and Vuidot et al. (2011) found a relationship with diameter even after a few decades of abandonment, but also in managed forests (Vuidot et al. 2011). Conversely, positive correlations between the abundance of TreMs and the stem DBH were found in forests left unmanaged for centuries. A greater variability of disturbance-generated TreMs and stand structural elements could possibly be found on a long-time scale, owing to the time needed to develop habitat and resource requirements for forest organisms. The effect of forest management, or its absence, on the abundance of TreMs was also shown in other studies (Michel \& Winter 2009, Winter et al. 2005). At tree level, Vuidot et al. (2011) demonstrated that, whatever form of forest management, the number and type of TreMs were mainly influenced by individual tree features, and the probability of a certain density of TreMs was the same for similar trees.

Especially for living trees, abundance of TreMs was higher in forests that had been left unmanaged for long. Conversely, abundance of TreMs was much lower in forests in which the last harvest dated back a few decades (30-50 years). This highlighted how the time since the last harvest was a major factor in determining forest structure (e.g., stem DBH, tree density) and microclimate (e.g., light penetration, moisture availability), in turn affecting the formation of TreMs on living trees. Regnery et al. (2013) obtained similar results in Mediterranean forests. Vuidot et al. (2011), Larrieu \& Cabanettes (2012) and Regnery et al. (2013) found that snags were richer in TreMs than living trees. In unmanaged forests located in mountainous regions of France, Paillet et al. (2017) found that the higher density of TreMs was not only due to the higher occurrence of favourable elements (e.g., large trees and snags), but also to the fact that trees might host more TreMs when the forest was unharvested for long. Furthermore, it was also confirmed that large trees and dead trees could host more TreeMs than their smaller or living counterparts did (Paillet et al. 2019). Also, in our study sites, regardless of the environmental conditions, the abandonment of management practices favoured the abundance and diversity of TreMs.

We found that snag (1.4 TreMs per element) and CWD (0.8 TreMs per element) were the richest deadwood components in TreMs (in total 879 TreMs, equal to $74.6 \%$ of all TreMs recorded). The role of CWD in providing TreMs was particularly important when the woody debris occurring on the forest floor were of large dimensions. This was particularly evident in forest stands that had been unmanaged for more than 100 years. The abundance of TreMs on CWD was high, though the lack of studies that consider the abundance of TreMs on this deadwood component hinders any comparison. In analogy with the single large vs. several small discussion (Larrieu et al. 2018), it is still unclear whether high biodiversity is associated with higher availability of several small elements rather than to one single large element. Indeed, at the plot level, since each tree is a potential host of TreMs, forest stands with a low number of trees may also show a reduction in the abundance and diversity of TreMs (Johann \& Schaich 2016). Conversely, we observed that the highest diversity of TreMs was observed in Area Pavari, where the tree density was very low (191 trees per hectare). By contrast, in Abeti Soprani, in which 591 trees per hectare occurred, the diversity of TreMs was lower. We suggest that tree size and stand characteristics had key role in determining the abundance of TreMs. In particular, trees in Area Pavari were characterized by very large size, then increasing the probability to host valuable TreMs combinations for biodiversity conservation. In this sense, the preservation of big living trees, large deadwood elements, and old-growth forest patches might help promote structural diversity, in turn preserve TreMs. Nevertheless, a combination of single large and several small deadwood elements (and living trees) might represent a good compromise in sustainable forest management approaches, but it should be evaluated in relation to the species at stake.

In addition, differences in the abundance of TreMs among sites were influenced by the time since the last harvest. We found that the abundance of TreMs, especially for deadwood components, in comparison with living trees, was higher in those sites in which the last harvest dated back more than three centuries. Higher amount of TreMs on deadwood components than on living trees was also detected in deciduous oak forests, in central Italy, by Parisi et al. (2019). An exception was observed in Bosco Aschiero, where living trees hosted more numerous TreMs than deadwood components. Studying the abundance of TreMs on living trees or on SDT and snags has often been favoured (Paillet et al. 2017), while few studies (Winter et al. 2005, Parisi et al. 2016, 2019) have considered the abundance of TreMs on other deadwood components, such as stumps, CWD and DDT. Considering the deadwood components, the most common TreMs were the holes and the system of gallery (M22 and M23) originated by saproxylics (Bouget et al. 2014, Parisi et al. 2018).

The most numerous TreMs observed on living trees was $\mathrm{M}_{4}$ (broken crown). The number of M4 found in our sites (16 TreMs per ha) was higher than in Paillet et al. (2017) and in Bouget et al. (2014), who observed 8-12 and 5-8 TreMs per ha, respectively. In these Mediterranean mountains, heavy snow and windstorms may cause considerable damage to tree crowns, particularly in old trees, making them susceptible to secondary attacks by pests and fungi. The resulting array of substrates and resources for decomposers is of relevance for conservation (Bani et al. 2018, Parisi et al. 2018). A better understanding of TreMs dynamics and of the complex interrelations between forest biodiversity and environmental disturbance is warranted to integrate monitoring protocols into conservation strategies and sustainable management of forests. Some proportions of all development phases of the forest, including senescence patches and canopy gaps, caused by the death of one or more trees, as well as different stand densities, should be regarded as having high conservation value in recognition of the role they play in ecosystem processes and in maintaining biodiversity in these Mediterranean mountain forests of high nature value.

In total, the CWD hosted more TreMs (694) than other deadwood components. However, SI highlighted how the diversity of TreMs was particularly high on living trees. Snags and DDT were also characterized by fair diversity of TreMs. Paillet et al. (2017) recognized snags as substrates that might increase the occurrence of TreMs. Yet, SDT might favour the occurrence of TreMs, either in terms of total number (Vuidot et al. 2011), diversity, or types (Larrieu et al. 2012). For living trees, high SI was observed in Val Cervara and Fonte Novello, and then in Area Pavari and Bosco Aschiero. These sites were characterized by a similar stand structure, especially for the presence of large trees $(\mathrm{DBH}>80 \mathrm{~cm})$. For this reason, the time since the last harvest was not the main factor influencing the abundance of TreMs. As an example, in Area Pavari, where the last harvest dated back at least six decades, SI was higher than in Bosco Aschiero, unmanaged for more than three centuries. Indeed, the stem DBH was the principal dendrometric parameter that in- 
fluenced the abundance of TreMs and a positive correlation between stem DBH of living trees and the abundance of TreMs was also observed in other studies (Regnery et al. 2013, Paillet et al. 2017). In addition, the presence of large trees might also increase the diversity and the abundance of some particular types of TreMs (Larrieu et al. 2014, Vuidot et al. 2011), such as bark loss or branch damages (Michel \& Winter 2009).

The presence of large trees could, therefore, be considered an appropriate indicator of forest biodiversity (Lindenmayer et al. 2014, Lindenmayer 2017), also in these Mediterranean mountain areas, and provide effective monitoring schemes and help identify alternative management strategies. As an example, variable-density thinning might contribute to increase the relative proportion of large trees, in turn enhancing the density and spatial distribution of TreMs. Nevertheless, also small trees would provide TreMs (Großmann et al. 2018). Whether TreMs can be used as valuable forest structure indicators of biodiversity in forest monitoring schemes is still a matter of debate. Indeed, it is a matter of fact that TreMs should be always integrated with the measurement of other indicators, such as deadwood (e.g., standing dead trees and snags), in evaluating biodiversity, especially for some taxa, such as birds and bats (Paillet et al. 2018).

Referring to perspectives for forest management, results may help understand trade-offs of integrative vs. segregative approaches for the conservation of forest biodiversity. Old-growth forests provide unique habitats for numerous species of animals and fungi that evolved in environmental conditions regulated by natural processes (Seymour et al. 2002). Oldgrowth forest patches might help to better recover large-scale effects of forest management in Mediterranean landscapes of Europe, restoring biodiversity in degraded areas on a regional scale. The segregation of high nature value forests would provide habitat for old-growth dependent species, balancing sustainable timber production targeted in managed forests. Nevertheless, the integration of nature conservation and economic management should still consider late-successional forest stages to compensate rotations for timber production that are much shorter than the lifespan of trees. Unravelling these complex relationships between forest structure, component size, and species diversity requires further research in both old-growth and managed forests across Europe. Therefore, for conservation purposes at the landscape scale, the occurrence of all the successional phases of a forest stand should be favoured (Hilmers et al. 2018). In this sense, biomass demands might interfere with conservation strategies in these Mediterranean mountain forests, and wise management practices need to be adopted to balance trade-offs between increasing demand for fuel wood and decreasing proportion of habitat trees in managed forests.

\section{Conclusions}

Tree features affected the abundance and diversity of TreMs in unmanaged forests in the Italian Apennines. Abundance and diversity of TreMs were mainly influenced by the stem DBH and the years since the last harvest. The combination of these two factors highlighted a significant increase of TreMs abundance and diversity in these old-growth forest patches.

Structural diversity at the stand scale increased proportionally with the time since the last harvest. Restoration towards old forest structures, such as extending rotation periods and retaining large trees (i.e., habitat trees), as well as snags and CWD, might represent suitable management strategies to preserve important TreMs and biodiversity in managed forests of high nature value in Mediterranean mountain ranges, while maintaining forest production.

Considering the current pattern of land abandonment in the Apennines, as well as other mountain areas throughout Europe, evidence on the abundance and types of TreMs would become useful indicators of naturalness within national forest inventory protocols and monitoring schemes, as anticipated for deadwood. Indeed, TreMs might act as biodiversity incubation centres, and their occurrence and types could be easily recorded in the field and be implemented in guidelines and prescriptions for the conservation of biodiversity, especially when managing forests for complexity (Puettmann et al. 2009).

\section{Acknowledgements}

The research is linked to activities conducted within the COST (European Cooperation in Science and Technology) Action CLIMO (Climate-Smart Forestry in Mountain Regions - CA15226) financially supported by the EU Framework Programme for Research and Innovation HORIZON 2020.

We thank the anonymous reviewers for their careful reading of our manuscript; their many insightful comments and suggestions significantly helped us to improve and clarify the manuscript.

\section{References}

Bani A, Pioli S, Ventura M, Panzacchi P, Borruso L, Tognetti R, Tonon G, Brusetti L (2018). The role of microbial community in the decomposition of leaf litter and deadwood. Applied Soil Ecology 126: 75-84. - doi: 10.1016/j.apsoil.2018. 02.017

Bouget C, Larrieu L, Brin A (2014). Key features for saproxylic beetle diversity derived from rapid habitat assessment in temperate forests. Ecological Indicators 36: 656-664. - doi: 10.1016/ j.ecolind.2013.09.031

Bütler R, Lachat T, Larrieu L, Paillet Y (2013). Habitat trees: key elements for forest biodiversity. In: "Integrative Approaches as an Oppor- tunity for the Conservation of Forest Biodiversity". European Forest Institute, Joensuu, Finland, pp. 284. [online] URL: http://www.re searchgate.net/publication/308050296

Dixon PM (1993). The bootstrap and the jackknife: describing the precision of ecological indices. In: "Design and Analysis of Ecological Experiments" (Scheiner SM, Gurevitch J eds). Chapman and Hall, New York, USA, pp. 290-318. [online] URL: http://books.google.com/books? id=pNpCoPe4mt4C

Emborg J, Christensen M, Heilmann-Clausen J (2000). The structural dynamics of Suserup Skov, a near-natural temperate deciduous forest in Denmark. Forest Ecology and Management 126: 173-189. - doi: 10.1016/So378-1127(99) ooog4-8

Großmann J, Schultze J, Bauhus J, Pyttel P (2018). Predictors of microhabitat frequency and diversity in mixed mountain forests in South-Western Germany. Forests 9: 104. - doi: $10.3390 / f 9030104$

Grove SJ (2002). Saproxylic insect ecology and the sustainable management of forests. Annual Review of Ecology and Systematics 33: 1-23. doi: 10.1146/annurev.ecolsys.33.010802.150507 Hilmers T, Friess N, Bässler C, Heurich M, Brandl R, Pretzsch H, Seidl Müller R J (2018). Biodiversity along temperate forest succession. Journal of Applied Ecology 55: 2756-2766. - doi: 10.1111/ 1365-2664.13238

Hunter ML (1990). Wildlife, forests, and forestry. Principles of managing forests for biological diversity. Prentice Hall, Englewood Cliffs, New Jersey, USA, pp. 370. [online] URL: http://www. cabdirect.org/cabdirect/abstract/19910654124

Johann F, Schaich H (2016). Land ownership affects diversity and abundance of tree microhabitats in deciduous temperate forests. Forest Ecology and Management 380: 70-81. - doi: 10.1016/j.foreco.2016.08.037

Kozák $D$, Mikoláš $M$, Svitok $M$, Bače $R$, Paillet $Y$, Larrieu L, Nagel TA, Begovič K, Cada V, Diku A, Frankovič M, Janda P, Kameniar O, Keren S, Kjučukov P, Lábusová J, Langbehn T, Málek J, Mikac S, Morrissey RC, Nováková MH, Schurrman JS, Svobodová K, Synek M, Teodosiu M, Toromani E, Trotsiuk V, Vítková L, Svoboda M (2018). Profile of tree-related microhabitats in European primary beech-dominated forests. Forest Ecology and Management 429 (10): 363 374. - doi: 10.1016/j.foreco.2018.07.021

Lambert D (1992). Zero-inflated Poisson regression, with an application to defects in manufacturing. Technometrics 34: 1-14. - doi: 10.2307/ 1269547

Larrieu L, Cabanettes A (2012). Species, live status, and diameter are important tree features for diversity and abundance of tree microhabitats in subnatural montane beech-fir forests. Canadian Journal of Forest Research 42: 1433 1445. - doi: 10.1139/X2012-077

Larrieu L, Cabanettes A, Delarue A (2012). Impact of silviculture on dead wood and on the distribution and frequency of tree microhabitats in montane beech-fir forests of the Pyrenees. European Journal of Forest Research 131: 773-786. - doi: 10.1007/s10342-011-0551-z

Larrieu L, Cabanettes A, Gonin P, Lachat T, Paillet Y, Winter S, Bouget C, Deconchat M (2014). Deadwood and tree microhabitat dynamics in 
unharvested temperate mountain mixed forests: a life-cycle approach to biodiversity monitoring. Forest Ecology and Management 334: 163-173. - doi: 10.1016/j.foreco.2014.09.007 Larrieu L, Cabanettes A, Gouix N, Burnel L, Bouget C, Deconchat M (2017). Development over time of the tree-related microhabitat profile: the case of lowland beech-oak coppice-withstandards set-aside stands in France. European Journal of Forest Research 136: 37-49. - doi: 10.1007/s10342-016-1006-3

Larrieu L, Paillet $Y$, Winter $S$, Bütler R, Kraus $D$, Krumm F, Thibault L, Michel AK, Regnery B, Vandekerkhove $K$ (2018). Tree related microhabitats in temperate and Mediterranean European forests: a hierarchical typology for inventory standardization. Ecological Indicators 84: 194-207. - doi: 10.1016/J.ECOLIND.2017.08.051

Lindenmayer DB (2017). Conserving large old trees as small natural features. Biological Conservation 211: 51-59. - doi: 10.1016/J.BIOCON.201 6.11 .012

Lindenmayer DB, Banks SC, Laurance WF, Franklin JF, Likens GE (2014). Broad decline of populations of large old trees. Conservation Letters 7: 72-73. - doi: 10.1111/conl.12079

Lombardi F, Lasserre B, Chirici G, Tognetti R, Marchetti $M$ (2012). Deadwood occurrence and forest structure as indicators of old-growth forest conditions in Mediterranean mountainous ecosystems. Écoscience 19 (4): 344-355. - doi: 10.2980/19-4-3506

Lombardi F, Marchetti M, Corona P, Merlini P, Chirici G, Tognetti R, Burrascano S, Alivernini A, Puletti N (2015). Quantifying the effect of sampling plot size on the estimation of structural indicators in old-growth forest stands. Forest Ecology and Management 346: 89-97. - doi: 10.1016/j.foreco.2015.02.011

Marchetti M, Tognetti R, Lombardi F, Chiavetta U, Palumbo G, Sellitto M, Colombo C, lovieno P, Alfani A, Baldantoni D, Barbati A, Ferrari B, Bonacquisti S, Capotorti G, Copiz R, Blasi C (2010). Ecological portrayal of old-growth forests and persistent woodlands in the Cilento and Vallo di Diano National Park (southern Italy). Plant Biosystems 144: 130-147. - doi: 10.1080/ 11263500903560470

Marti JA (2001). A new method for non-parametric multivariate analysis of variance. Austral Ecology 26: 32-46. - doi: 10.1111/j.1442-9993.2001. 01070.pp.x

McArdle BH, Anderson MJ (2001). Fitting multivariate model to semi-metric distances: a comment on distance-based redundancy analysis. Ecology 82: 290-297. - doi: 10.1890/0012-9658

Michel AK, Winter S (2009). Tree microhabitat structures as indicators of biodiversity in Douglas-fir forests of different stand ages and management histories in the Pacific Northwest,
USA. Forest Ecology and Management 257: 1453-1464. - doi: 10.1016/J.FORECO.2008.11.027 Nagel TA, Svoboda M, Diaci J (2006). Regeneration patterns after intermediate wind disturbance in an old-growth Fagus-Abies forest in southeastern Slovenia. Forest Ecology and Management 226: 268-278. - doi: 10.1016/j.for eco.2006.01.039

Paillet $\mathrm{Y}$, Archaux F, Puy S, Bouget C, Boulanger V, Debaive N, Gilg O, Gosselin F, Guilbert E (2018). The indicator side of tree microhabitats: a multi-taxon approach based on bats, birds and saproxylic beetles. Journal of Applied Ecology 55: 2147-2159. - doi: 10.1111/1365-2664.13181 Paillet $\mathrm{Y}$, Archaux F, Boulanger $\mathrm{V}$, Debaive $\mathrm{N}$, Fuhr M, Gilg O, Gosselin F, Guilbert E (2017). Snags and large trees drive higher tree microhabitat densities in strict forest reserves. Forest Ecology and Management 389: 176-186. doi: 10.1016/J.FORECO.2016.12.014

Paillet Y, Debaive N, Archaux F, Cateau E, Gilg O, Guilbert E (2019). Nothing else matters? Tree diameter and living status have more effects than biogeoclimatic context on microhabitat number and occurrence: an analysis in French forest reserves. PLoS One 14 (5): e0216500. doi: 10.1371/journal.pone.0216500

Parisi F, Lombardi F, Sciarretta A, Tognetti R, Campanaro A, Marchetti $M$, Trematerra $P$ (2016). Spatial patterns of saproxylic beetles in a relic silver fir forest (Central Italy), relationships with forest structure and biodiversity indicators. Forest Ecology and Management 381: 217-234. - doi: 10.1016/j.foreco.2016.09.041

Parisi F, Pioli S, Lombardi F, Fravolini G, Marchetti $M$, Tognetti $R$ (2018). Linking deadwood traits with saproxylic invertebrates and fungi in European forests - a review. iForest 11: 423-436. - doi: 10.3832/ifor2670-011

Parisi F, Di Febbraro M, Lombardi F, Biscaccianti $A B$, Campanaro A, Tognetti R, Marchetti M (2019). Relationships between stand structural attributes and saproxylic beetle abundance in a Mediterranean broadleaved mixed forest. Forest Ecology and Management 432: 957-966. doi: 10.1016/J.FORECO.2018.10.040

Parisi F, Lombardi F, Marziliano PA, Russo D, De Cristofaro A, Marchetti M, Tognetti R (2020). Diversity of saproxylic beetle communities in chestnut agroforestry systems. iForest 13: 456465. - doi: 10.3832/ifor3478-013

Peterken GF (1996). Natural woodland: ecology and conservation in northern temperate regions. Cambridge University Press, Cambridge, UK, pp. 540. [online] URL: http://books.google. com/books?id=p3y43NnvXPYC

Puettmann K, Coates D, Messier C (2009). A critique of silviculture: managing for complexity. Island Press, Washington, DC, USA, pp. 188. [online] URL: http://www.proquest.com/open view/ed95c1ba7898d93e299dccc5adad1904/1 R Core Team (2019). R: a language and environment for statistical computing. R Foundation for Statistical Computing, Vienna, Austria. [online] URL: http://www.r-project.org

Regnery B, Paillet $Y$, Couvet D, Kerbiriou C (2013). Which factors influence the occurrence and density of tree microhabitats in Mediterranean oak forests? Forest Ecology and Management 295: 118-125. - doi: 10.1016/j.foreco.20 13.01.009

Rosenvald R, Lõhmus A (2008). For what, when, and where is green-tree retention better than clear-cutting? A review of the biodiversity aspects. Forest Ecology and Management 255 (1): 1-15. - doi: 10.1016/j.foreco.2007.09.016

Seymour RS, White AS, De Maynadier PG (2002). Natural disturbance regimes in northeastern North America - evaluating silvicultural systems using natural scales and frequencies. Forest Ecology and Management 155: 357-367. - doi: 10.1016/S0378-1127(01)00572-2

Shannon CE (1948). A mathematical theory of communication. Bell System Technical Journal 27 (4): 623-656. - doi: 10.1002/j.1538-7305.194 8.tbo1338.x

Stokland JN, Siitonen J, Jonsson BG (2012). Biodiversity in dead wood. Cambridge University Press, New York, NY, USA, pp. 524.

Tabacchi G, Di Cosmo L, Gasparini P (2011). Aboveground tree volume and phytomass prediction equations for forest species in Italy. European Journal of Forest Research 130: 911-934. - doi: 10.1007/s10342-011-0481-9

Vuidot A, Paillet Y, Archaux F, Gosselin F (2011). Influence of tree characteristics and forest management on tree microhabitats. Biological Conservation 144: 441-450. - doi: 10.1016/j.bio con.2010.09.030

Winter S, Flade M, Schumacher H, Kerstan E, Möller G (2005). The Importance of near-natural stand structures for the biocoenosis of lowland beech forests. Forest, Snow and Landscape Research 79 (1): 127-144.

Winter S, Möller GC (2008). Microhabitats in lowland beech forests as monitoring tool for nature conservation. Forest Ecology and Management 255: 1251-1261. - doi: 10.1016/j.foreco.20 07.10 .029

Zuur AF, leno EN, Elphick CS (2010). A protocol for data exploration to avoid common statistical problems. Methods in Ecology and Evolution 1 (1): 3-14. - doi: 10.1111/j.2041-210X.2009.00 001. $x$

Zuur AF, Hilbe JM, leno EN (2013). A beginner's guide to GLM and GLMM with R: a frequentist and Bayesian perspective for ecologists. Highland Statistics Ltd., Newburgh, UK, pp. 256. 